\title{
Analysis of The Implementation of Public Relations Function at The Department of Industrial and Trading of Yogyakarta in Improving The Market Quality
}

\author{
Via Alfian Ika Agustina ${ }^{1}$, Siti Fatonah ${ }^{2}$, Muhammad Edy Susilo ${ }^{3}$ \\ 1,2,3 Ilmu Komunikasi, Fakultas Ilmu Sosial dan Ilmu Politik, Universitas Pembangunan Nasional "Veteran" Yogyakarta \\ 1,2.3 Jalan Babarsari 2, Tambakbayan, Yogyakarta 55281, Indonesia \\ Email: viaalfianikaa@yahoo.com ${ }^{1}$; ona_cahya@yahoo.co.id ${ }^{2} ;$ muh_edy_susilo@yahoo.co.id $^{3}$ \\ *corresponding author
}

\begin{abstract}
Department of Industrial and Trading of Yogyakarta does not have any Public Relations Officer (PRO), but they continue its implementation of Public Relations function for increasing market quality. The objective of this study are to find out the implementation of Public Relations function from this department. Situational Theory of the Publics, The Concept of PR's Function, and SWOT Analysis will be guide for this study. This study is a qualitative descriptive, in the interest of investigate, measuring, and interpreting the problems of this study. The results shows that this department is implement Public Relations functions in many kind of activities, include Press Agentry, Public Affair and Community Relations, Inovations, and Branding Strategy. Functions implemented by this department are: maintain a good relationship with their publics, create the corporate image, communications between organization and publics, and make programs for all the publics. Based on the results, SWOT Analysis, and Situational Theory of The Publics, the implementation has not been succeed. This is due to the inability of identifying the publics, fulfill its wishes, and find out the right strategy. In the other words, the failure comes out because there is no Public Relations in this department. The contribution of this research is in the form of policy recommendations to other organizations to implement the public relations function as much as possible to achieve the objectives of the program. Keywords: Government Public Relations, Sosializations, Programs
\end{abstract}

\begin{abstract}
Abstrak
Dinas Perindustrian dan Perdagangan Kota Yogyakarta tidak memiliki Public Relations Officer (PRO), namun tetap mengimplementasikan fungsi Public Relations dalam meningkatkan kualitas pasar. Tujuan dari penelitian ini untuk mengetahui implementasi fungsi Public Relations dari Dinas Perindustrian dan Perdagangan Kota Yogyakarta. Acuan yang digunakan yaitu Situational Theory of the Publics, Konsep Fungsi PR, dan Analisis SWOT. Penelitian ini merupakan penelitian kualitatif dengan metode deskriptif, untuk meneliti, mengukur, dan memberikan pemaknaan terhadap permasalahan penelitian. Hasil penelitian menunjukkan bahwa pihaknya mengimplementasikan fungsi Public Relations melalui berbagai kegiatan yang berbentuk Press Agentry, Public Affair dan Community Relations, Inovasi, dan Strategi Branding. Fungsi Public Relations yang diimplementasikan yaitu: Membina hubungan positif dengan publik, Menciptakan citra perusahaan atau lembaga, Komunikasi 2 arah antara organisasi dengan publiknya, dan Program yang memfokuskan semua publik organisasi. Berdasarkan hasil penelitian yang dianalisa dengan Analisis SWOT dan Situational Theory of The Publics, pihaknya belum mengimplementasikan fungsi Public Relations dengan maksimal terlihat dari belum tercapainya tujuan program. Hal ini dikarenakan belum mampunya untuk mengidentifikasi publik, mengakomodasi keinginannya, dan menentukan strategi yang tepat. Dapat dikatakan bahwa belum suksesnya sosialisasi dan pelaksanaan program ini karena Dinas Perindustrian dan Perdagangan Kota Yogyakarta tidak memiliki Public Relations Officer. Kontribusi penelitian ini berupa rekomendasi kebijakan kepada organisasi lain untuk menerapkan fungsi public relation semaksimal mungkin agar tercapainya tujuan program. Kata Kunci: Humas Pemerintahan, Sosialisasi, Program
\end{abstract}

\section{Introduction}

An institution necessarily has a purpose that is usually shows in the vision, mission, and programs. The purpose of the institution is usually very common and widespread, which means that the institution should perform its assortment of businesses in various fields. To that end, an institution needs to make a variety of divisions with regard to the efforts that need to be done in achieving its goals. One of the divisions of a must-have, namely Public Relations. Public Relations is one of the important 
components in the body of the organization. If the organization likened as a tree, it can be said that Public Relations is the rod that connects to every part of the tree. This is due to its being a liaison between organizations with different parties. Parties who have a relationship with an organization called the public (stakeholders), so the practitioner on duty to ensure a good relationship with the public organization called the Public Relations. This is following the research of Astuty, Setyastuti, Maulina, and Hanief (2018) which states that public relations must create cooperation and the emergence of public trust in organizations and stakeholders. This research focuses on the implementation of the Public Relations function of the Yogyakarta City Industry and Trade Office. Managerial skills and techniques owned PR is very important and crucial. This is due to: PR can monitor public opinion; PR can represent the interests of the public and predicted the public reaction against management decision; PR has a good ability in collecting data and information (Prayudi, 2016:239).

The the oretical data over if seen in real life, can be illustrated by the successness of the Xpander thanks to the performance of Public Relations. Within just a few months after the launch, sales have reached 27 thousand units or $27 \%$ of the market Small MPV. In fact, throughout January 2018, sales already approaching incumbent brands, Toyota Avanza, with only a difference in hundreds of units (Wulandari, MIX Magazine 02/XV, 2018).

See explanation above, then ideally every organization has Public Relations. Public Relations practitioners are able to establish rapport and improving employee performance (Ruliana et.all, 2018) with the lowest staff internal to the Board of Directors; external relationship with diverse public; doing publicity, advertising, research, and events; improve the quality of the organization's resources; to responsible for the resolution of issues and crisis. If you don't have Public Relations, then the organization can lose such opportunities. For the example, there are prolonged crisis of Suramadu Region Development Agency (BPWS) since 1990 up to 2013, because the BPWS did not manage to deal with the attitudes of the various public and the absence of Public Relations in the organization. In carrying out its tasks, it gets a reaction of resistance from the local government County of Bangkalan, Bangkalan Scholars (BASSRA), activists and NGOs Bangkalan Regency, and street vendors (STREET VENDORS) is Locality Suramadu. (Yuliatin, 2017:29-35).

From this crisis, only in 2012 BPWS "Donate" State losses up to Rp. 320 million. Even until the year 2017, the crisis has not yet successfully dealt with it well. As a result, the Surabaya Suramadu submitted to managed private parties. Given the urgency, a number of organizations have been running the practice of Public Relations, from the business, political parties, educational institutions, as well as the Government. Organizations that have Public Relations in between PT Astra International, Bank Mandiri, University of Gajah Mada, Advertising Associations of Indonesia (P3I), and Governments of the region. There are even companies who finally decided to set up a Public Relations Division, namely Traveloka. It viewed that Public Relations is more able to increase sales and can create brand image.

Even so, many organizations that have not been considered important the existence of Public Relations. In Indonesia itself, the practice of Public Relations is assessed is still minimal. Jan Quarles, a professor of public relations, describes the practice of PR in Indonesia in just a short paragraph in his book. According to him, there are only few companies engaged in the field of PUBLIC RELATIONS in Jakarta.

It is also apparent from the data on the website of the Ministry for the empowerment of State apparatus related number of a civil State Apparatus and Functional Institution 
of public relations that the sum of the civil State Apparatus (ASN) as much as 4,517,126 employees serving 252 million inhabitants. The Worldwide Governance Indicators Reports show that the average value of the effectiveness of the Government of Indonesia is still lower with index values-0.01 (ranked 85). The number of implementing public communication service, namely the labor functional institution publicist who became part of the Government Public Relations (GPR) is ideally appropriate for position analysis ditakar the entire ministries, agencies, and areas throughout Indonesia, reach twelve thousand men. However, up to now the new available 1,576 ASN that qualify as functional PR government agencies (Menpan, 2018).

Though limited in number, it can be said that the practice of Public Relations in Indonesia. Practice is not only done by business enterprises, but also on government institutions as has been mentioned above. The Government needs to do the practice of Public Relations in order to provide information about a lot of things to the community. Through Public Relations, the Government can "set up" public opinion and gain support in the eyes of the community.

Basically, any person or organization inevitably require Public Relations. As according to Clara (2001:1), "everyone is basically always have a publicist, unless he is a tarzan who never meet or establish contact with other human beings". There is also a research thesis "communication organization in a company that doesn't have a Public Relations (study on PT Gotrans Engineering)" which essentially indicates that the company is still run Public Relations activity though not have a Public Relations Officer (Meisaputra, 2016). It is more or less the same with the Department of Industrial and Trading of the city of Yogyakarta which still conduct Public Relations even though it doesn't haveaPublic Relations Officer(PRO)inparticular.

It performs some tasks that are a form of Public Relations functions as become a Public
Affair, do the development, as well as doing branding, publications, community relations, for example in cooperation with the bond Women Entrepreneurs (IWAPI) Indonesia to improve the small and medium Industrial (IKM); media relations and conducted fruitful some news, including news on online media titled "President Jokowi Praise Kranggan Market Hygiene."

Department of Industrial and Trading of the city of Yogyakarta has the task and goal-related industries sector production, trading, as well as the management and development of the market. To be able to achieve its objectives, this office has a work program that requires it to connect with the public concerned. The program will be implemented if the Department of Industrial and Trading of the city can establish good relations with the public. On the program in the sector of Trading, Industrial and Service Trading in the city of Yogyakarta has the task to improve the quality of the market with the sub program commonly called a "Pasare Resik, Atine Becik, Rejekine Apik, Sing Tuku Ora Kecelik". Through this program, the Department of Industrial and Trading of the city want to realize the market is clean and comfortable for Tradingrs as well as buyers, who can increase revenues and market economy society. In implementing this program, the Department works closely with the Tradingrs, who manages the parking lot, a janitor, a community, and some other public.

With the diversity of the public as has been mentioned, not an easy thing to be able to give a proper handling. This is due to a diverse public, certainly requires different handling. All have to be accommodated because of the effect on the program achievements. Especially in organizations that do not have a PRO, can so will have difficulty in providing services to the public and handling.

Amount to a bunch of specific public, for example Tradingrs, nor is it a little bit. In the strategic plan of Department of Industrial and Trading of the city of Yogyakarta (2017:33-37), 
provided the number of merchants who built countless until the year 2018 are at numbers 2,111 people Tradingrs, whereas in its realization until the year 2018 the amount of the Tradingr built only 912 people Tradingrs. The number of perpetrators of micro enterprises until the year 2018 i.e. 760 people, with the realization of the perpetrators of the micro enterprise successfully facilitated just 640 people. If viewed from the side of buyer or visitors that are on the market, an increase in every year. According to the data Management service of the market that has the task of managing the market prior to the merger was held with Department of Industrial and Trading of the city, the number of visitors to the market i.e. 136,283 persons per days (2013), 139,882 persons per days (2014), 141,041 persons/days (2015). Then from the 20162018 period, the number of visits this market increased by approximately $36 \%$ per year.

A large number of Tradingrs and the growing market in addition to the visits can be an advantage, it can also be public relations to accommodate what the wishes of the public. Therefore, it tries to perform the function of Public Relations. Functions of Public Relations is a planned and organized activities of a company or institution that has a value of benefits, to create relationships of mutual work together, transmit information, as well as publications for the sake of realizing the purpose of the institution or organization. According to Smith (Prayudi, 2016:9-12), the functions of Public Relations: two-way communication between public organizations, mutually beneficial Relationship between public organizations, functions, management and leadership, planned Efforts and seriously affect public policy and opinion, communication to all public organizations, organizational means of managing reputation better.

Department of Industrial and Trading of the city perform the function of Public Relations to achieve their goals. The extent to which the Public Relations function is implemented and what shape are performed, reviewed and rated based on a Situational Theory of The Number with the SWOT analysis. Situational Theory of the Number because it can be used to explain problems of research. According to Kriyantono (2014:152), the Situational Theory of the Number is a useful theory to identify the public, so as to make the category more specific public with behavior based on communications from individuals and the effects of communication the accepted individual. This is done to ensure that the communication of the message delivered by $\mathrm{PR}$ practitioners really suits the needs of their target. Number referred to here as journalists, employees, investors, consumers, Government, or local community.

This theory in General discuss about how the Organization identifies the publicpublic. The diverse public requires that the Organization, in particular the Public Relations practitioners mapped out how relations should be built on each of the public. Department of Industrial and Trading of the city has many heterogeneous public, including Tradingrs, buyers, communities, labour, cleaning service. In fact, the task of building a relationship conducted by Public Relations Officer, but the Department of Industrial and Trading of the city does not have it. This theory also suggests that in certain situations, every public will give different reactions. This reaction requires different handling. In this study, the situation is that socialization program, while the handling is meant i.e. activities which is the function of Public Relations. From the handling of the situation made can be assessed, how the Public Relations function is implemented. This assessment will be carried out using a SWOT analysis.

According to Freddy Rangkuti (2004:18), SWOT analysis is an analysis of the internal and external conditions of an organization which will then be used as the basis for designing a strategy and work programme. On the SWOT analysis, there is an Internal Analysis that includes 
assessment of the Power factor (S) and weaknesses (W) as well as the analysis of the External factors include Opportunities (o) and challenges (T).

Strength (Strength) are elements that can be seeded by companies such as excellence in products that are reliable, have different skills, and with other products so as to make it more powerful than its competitors. Weakness (Weakness) is lack or limitations in terms of the resources that exist in the company either skills or abilities that become obstacles to the performance of the organization. Opportunity (Opportunity) is a variety of things and the situation is advantageous for a firm. Threats (Threats) are factors unfavorable environment in the company, if it is not resolved it will be barriers to the company either now or in the future.

The SWOT analysis is used to analyze the functions of Public Relations that are implemented by the Department of Industrial and Trading of the city based on the theory that is used. The goal in order to find out whether the Public Relations functions implemented already running properly or there is still a shortage, so that it can respond to problems with formulation is more accurate and can provide benefits as have been presented. Based on the above, the objective of this study are to find out the implementation of Public Relations function from this department.

\section{Research Methods}

This research is a kind of qualitative research. According to Sugiyono (2006:15), the qualitative approach is a method of research based on the philosophy of positivism-post and used to examine the condition of the natural object in which the researcher is key, as the instrument sampling in purposive nature of the inductive, data analysis, and the results underscore the meaning rather than generalities. Meanwhile, according to Strauss and Corbin (2009:4), qualitative research is the kind of research that her findings are not obtained through a statistical procedure or other forms of matter.
For example in the form of research about the life, history, and behavior of a person, in addition it is also about the role of the Organization, social movement, or a reciprocal relationship.

This research uses descriptive method. According to Fathoni (2006:97), descriptive research is a research that intends to hold examinations and measurements-measurements against certain symptoms. In accordance with that explanation, descriptive research was chosen because investigators intend to present the data in a systematic, factual, and accurate about the facts and the definition of the phenomenon in the field. Researchers intend to obtain data and facts regarding the implementation of the functions of Public Relations of the Department of Industrial and Trading of the city of Yogyakarta, which further analyzed and do purport.

Data used i.e. primary data (data activity implementation functions of the Public Relations Department of Industrial and Trading of the city of Yogyakarta from the observation and interviews with related parties) and secondary data (supporting data regarding the activity of the the implementation of the functions of the Public Relations Department of Industrial and Trading of the city of online news results study documentation).

To test the validity of research data carried out triangulation. In this research, used a type of triangulation data sources and methods. Researchers keep using primary data obtained from the subject as the subject matter, but also want to get data not only from one side only. Purpose is to make the data acquired more and diverse so clearly describes the phenomena examined. To that end, it will be done by: 1) Compare the results of interviews with the principal data observations; 2) Compare the results of interviews with the principal resource related issues; 3) Compare the State and perspectives of the various classes, with a free interview to Tradingrs, buyers, and other related public, especially existing in Beringharjo market. 


\section{Result of Research And Discussion}

An overview of Department of Industrial and Trading of the city of Yogyakarta Department of Industrial and Trading, or commonly known as Disperindag, is a service which is under the auspices of the Ministry of Industrial of the Republic of Indonesia and the Government of the city of Yogyakarta. Formerly, this Department became a part of the service Perkoperasian and Disperindagkop with the name of Disperindakop ESDM. Then, stand Service cooperatives and carried out the withdrawal authority Office of MINERAL RESOURCES at the provincial level. In line with this, made a merger between Disperindag and Market Management Office became the Department of Industrial and Trading. Similar with it, also founded Department of Industrial and Trading in the area of level II, namely the Department of Industrial and Trading. In the structure of government administration in the city of Yogyakarta, Department of Industrial and Trading of the city is part of the Government of the city of Yogyakarta. Therefore, what is the vision, mission, goals, and other things pertaining to the Department of Industrial and Trading of the city refers to the vision, mission, and goals of the City Government headed by the Mayor and Deputy Mayor. Department of Industrial and Trading of the city of Yogyakarta has the task of carrying out the Affairs of local governance based on the principle of autonomy and pembantuan tasks in the field of Industrial and Trading. Efforts to Improve the Quality Of Markets Through The Sub Program "Pasare Resik, Atine Becik, Rejekine Apik, Sing Tuku Ora Kecelik"

True to its name, the Department of Industrial and Trading of the city of Yogyakarta has the realm of employment in the sectors of Industrial and commerce. In the Trading sector, the Department of Industrial and Trading of the city has two major programs. The program i.e. Infrastructure Maintenance Program of cleanliness, security and order of the market as well as the Setup Program, development and revenue market.

In carrying out both the program, Congressional activity of Structuring the market Tradingrs and the construction of five feet and Peddlers; The construction, rehabilitation and maintenance of facilities and infrastructure market; and Intensification and Extensification of regional sources of Revenue Management Market Areas of Industrial that gathered in the Program "Pasare Resik, Atine Becik, Rejekine Apik, Sing Tuku Ora Kecelik ".

The program "Pasare Resik, Atine Becik, Rejekine Apik, Sing Tuku Ora Kecelik " has a meaning of "Clean market, a good Heart, good Fortune, the buyer was not disappointed". Through this program, the Department of Industrial and Trading of the city want to realize a clean and comfortable market through good service. Supported by the attitude of Tradingrs and market managers are friendly, honest and has integrity, is expected to create an atmosphere of the market become comfortable and fun. Both of these factors will support the presence of visitors and customer satisfaction so as to bring good fortune to Tradingrs. In practice, the Program "Pasare Resik, Atine Becik, Rejekine Apik, Sing Tuku Ora Kecelik " must be supported by Tradingrs, market manager, service, Government, and the rest of the element that is associated with this program. Therefore, the promotion and dissemination activities required to support the program. The shape of its activities such as shopping, promo competition, facilitation of adequate markets, and others. This program becomes a weapon to enhance the quality of the markets in the city of Yogyakarta. For the moment, its implementation is still focused in large markets such as Beringharjo market, market Trading of ornamental plants (PASTHY), and market Kranggan. However, the construction of the related programs are also conducted in other markets. 
Forms functions of Public Relations Department of Industrial and Trading of the city of Yogyakarta

Press Agentry

The activities of press agentry aims to increase the awareness of the community towards the Service Industrial of the city of Yogyakarta and the Program "Pasare Resik, Atine Becik, Rejekine Apik, Sing Tuku Ora Kecelik ". Activities held a large enough scale so that is expected to attract the attention of the public and the mass media. However, despite having a large enough scale, not all activities of Press Agentry done known by the public and the media. The activities are: Kirab Pedagang Pasar, The whole Batik "Batik International Biennale Jogja 2018", The race Blusukan Market (Outbound market), The race of Hygiene Market, and Coloring and Drawing Contest.

\section{Public Affairs and Community Relations}

Public Affairs function is a form of Public Relations by the Public Relations became the bridge to create and maintain the relationship between the Government and the public. Community Relations is a form of Public Relations functions for creating and maintaining the relationship between the Organization itself with local communities that became public, a relationship that was conducted on the needs and handling problems faced by the community, not the organization. The second form of the function of Public Relations is to be done by organizations such as the Department of Industrial and Trading of the city of Yogyakarta, which has programs that can run smoothly if it can be worked with a diverse public. The activities are: Gatherings of the merchant market and labours, Entertainment activities for Market Tradingrs, Training and Labour Market Tradingrs Carrying, Rest Room for Carrying Laborers and Janitor.

\section{Development \& Inovation}

Development activity or innovation done to improve services so that the relationship with the public-the public associated the better. Following the development activities initiated by the Department of Industrial and Trading of the city: E - Retribution, QR Code for Collecting Levies, and The computerized Data Processing of the Merchant.

\section{Branding Strategy}

Department of Industrial and Trading of the city of Yogyakarta is also doing Public Relations function which aims to create a good image of the Organization through the following activities: Resik-Resik Selasa Wage and Market Guide.

\section{Publications and Media Relations}

In showing its existence and "announce" the activities undertaken to improve the quality of the market, the Department of Industrial and Trading of the city doing the publications through the media-specific media. To do so, it strained relations with the media-appropriate media (media relations): Radio Suara Pasar (Radio part of the P3P Fields), Internal Media (Public Relations in the Government of Yogyakarta), and External Media. Obstacles encountered in carrying out the functions of Public Relations: The limited land for market development, Unruly Tradingrs, The higher request of consumer service, Lack of consumer awareness to maintain the cleanliness of the market, Lack of awareness to carry out Tera Ulang Timbangan, and a large number of traditional markets that became the responsibility of the Department of Industrial and Trading of the city of Yogyakarta. To overcome these barriers, handling efforts undertaken were: Optimize the land owned, Keep doing approach, Accommodate the desires of consumers, Do Tera Ulang Timbangan's Socialization, and Perform a gradual development. The implementation of the functions of the Public Relations Department of Industrial and Trading of the city of Yogyakarta

Establish or nurture positive and good relations with the public as target of target

In building relationships with the public with regard to the Organization, the Department of Industrial and Trading of the city doing activities 
where can create a relationship between them for the better, such as training, meetings, instruction, and entertainment activities for market Tradingrs and labourers carrying as well as the facilitation of the dugout carrying laborers and Tradingrs janitor.

On training held for merchant market, researchers assess that the training's been good because according to the needs of Tradingrs. On the training of Selling Online, though this training is the socialization of the new application the Government of the city of Yogyakarta, but still provides benefits for merchants. Training held for carrying workers, researchers assess that training needs to be given more than a Tradingr. This is because, the labor market that is in the carrying amount was far more than the needs of visitors against workers carrying. If items are purchased not too many or large, visitors often bring goods their own and declined the offer of the labour services carrying. If this is not considered serious, the longer labour of carrying will not be useful services, lost his job, and potentially being unemployed.

Much better if the Department of Industrial and Trading of the city doing coaching and training so that workers can have another job carrying, than if one had to address the problem of carrying workers who have become unemployed. In addition to the training that is still limited, any supplied break room is relatively small and narrow. With a large number of workers carrying, dugout supplied cannot accommodate the entire labour of carrying. The location of the break room located on the top floor at the most Eastern side of the market is also less strategic, because part of the Beringharjo market with a high level of visitor density is on the lower floor. It is labour that makes carrying prefer to rest in the alleys of the market bottom, and still went home a few days once (do not settle in space has been provided).

According to Canfield (in Ruslan, 2006:241), PR Activities in the world of Government should assume functions: (1) serve the public interest, (2) maintain good communication, (3) focuses on the moral and good behavior. In accordance with this, the Department of Industrial and Trading of the city has indeed implemented the first and second. However, see the explanation of related forms of the function performed, it can be said that the function has not been run.

\section{Create the image of a company or institution} (corporate image)

To create a positive image of the institution in the eyes of the public, the Department of Industrial and Trading of the city doing activities such as dress rehearsal-dress rehearsal Tuesday Wage, who can assure the public that the Program "Pasare Resik, Atine Becik, Rejekine Apik, Sing Tuku Ora Kecelik "implemented earnestly by the Agency.

It also provided to Guide the market during the holidays when the markets are a lot of visitors, as a service provider of information for the visitor market. With the guide of market, people are more comfortable and easy while shopping. Other activities such as Shopping Promo Giveaway is also done to attract the interests of society in order to shop at the market, especially in the framework of planning night market (a market which is open until the evening). According to Smith (in Prayudi 2016:912), Public Relations should be able to be the means by which the organization manages its reputation with the better. Activities to form positive image is done by the Department of Industrial and Trading of the city graded runs pretty well. For example, at the dress rehearsal activities-dress rehearsal Tuesday Wage, service give an example or role model, then the Tradingr and the market manager officer more increased consciousness for maintaining hygiene market. However, these activities became less effective, because the service has not been too publish activities so that there is the possibility of many visitors who don't know the business Office of Industrial and Trading of the city of Yogyakarta along with task force Tuesday Wage and This market Tradingrs. With that, the visitors have 
yet to realize the importance of pastisipasinya in maintaining the cleanliness of the market, so that garbage is still visible in some places.

However, Market Guide on providing researchers appraisers that are still less if only provided at holiday time. This is because, outside of any vacation time visitor market is quite crowded, even until the evening. While the security officer, who can be used as a source of information for visitors, only placed in the front side of the market and only one security guard on each floor.

\section{Two-way communication between organizations with public}

Socialization in order to attempt to improve the quality of the market, the Department of Industrial and Trading of the city runs the twoway communication. Communication from the Organization to the public e.g. by socialization direct or through certain media about the activities or policies of the Department of Industrial and Trading of the city of Yogyakarta. It also doesn't shut down communications from the public to the Organization, for example, when merchants reported a damaged infrastructure, carrying workers ask for healthcare facilities, and evaluation-evaluation of the activities provided on the player. This is a positive thing, considering the Department of Industrial and Trading of the city greatly need the support of the public in carrying out public-work program. With a good reception at the time of reporting, then immediately do the action to deal with it, will create trust and loyalty from the public-the public concerned.

According to Cutlip, Center and Broom (2011:466), the purpose of the Government's public relations include: Ensuring active collaboration in government programs; Encourage citizen support policies and programs that had already been set; Serve as a public advocate for government administrators - to convey the public opinion to the decision maker, manage public issues in the
Organization, increase public accessibility to the administrative officer. Points as an advocate of the public is already run by the second field of the Trading sector with good handling, but the first and second points haven't done well because only certain activities undertaken by the public. Programs that focus all public organizations

In conducting dissemination Program " Pasare Resik, Atine Becik, Rejekine Apik, Sing Tuku Ora Kecelik", Department of Industrial and Trading of the city of Yogyakarta has conducted various activities tailored to diverse public. For the Tradingr, regularly held gatherings and training, as well as entertainment activities. For his part, carrying workers routinely hold gatherings and training, as well as providing a break room. For the appreciation of the work of the janitor, it provides a break room and making it a task force Tuesday, K. For visitors, it provides a Sound, Radio market guide the market, and videotron contains information about markets and Office of Industrial and Trading. For children, it makes the race and gives the knowledge.

Department of Industrial and Trading of the city has indeed done a variety of ways to socialize the program. However, in practice there are still drawbacks. For example, the dugout is lacking adequate training and still less in price. Then there is the race of children who have yet to be implemented but already planned to do.

In a relationship with the public, researchers noticed that it forgets the media as public that also must be kept to do. Party service does not yet have the ability to read media interests, visible from all activities not implemented then reported by the media, even its own internal media. Wasesa and Macnamara (2010:170172) reveals that the relationship with the mass media has become limited to the relation of right and wrong, there is almost no efforts to build an agreement of the two parties. This is in accordance with what is going on between the Department of Industrial and Trading of the city of Yogyakarta with the media. 


\section{SWOT Analysis}

Strengh: A strategic Office Location with the purposes of socialization, in Beringharjo Market, Have adequate Human Resources in quantity, Have a lots of creative activities, Have already attracted great numbers of Tradingrs to participate in the activities, The level of product performance for the year 2016 of $95.28 \%$ entered the category of very high, Have a relationship of cooperation with many sides to socialize the program, has a strong legal basis for the programs and activities that are owned, have an adequate budget allocation for the programme (a Total of Rp. 5,982,111,913 to P3P Fields and Rp. 9,763,022,049 to SPK3P), and Have the assets and the proper equipment to process of dissemination and implementation program

Weakness: This Department does not have a Public Relations Officer in particular, Public Relations Functions being performed are not yet entirely, Not all activities carried out consistent to be held every year, Activities have not been too attracted media attention, Cannot form the active participation of the community to participate in the implementation of the program, The land for market development limited, The Status of some of the land market that still impede development so rent, The behaviour of Tradingrs who are still hard set in the process of repair facilities

Opportunities: The Mission of the Mayor of Yogyakarta strengthens people's economy and competitiveness, Yogyakarta become one of implementing the Program of the movement towards 100 Smart City, As the Centre of services, Yogyakarta as a tourism destination, The market is still a center of economic activities of the community of interest, The market became one of themain sources ofincome regional, The existence of a community of Tradingrs who proliferated.

Threats: A diverse Public, The abundance of desire from the public that need to be accommodated, Media delivering news that does not fit the facts, A dynamic development of technology in the Trading sector, The risk of damage to the means of supporting, The Rolling officers and changes in organizational structure that can not be estimated at the time, and the growth of modern markets. This research has implemented SWOT to improve market quality at The Department of Industrial and Trading of Yogyakarta. This is similar to research conducted by Pramudyanto (2018) that SWOT is important to do because SWOT is a strategic effort in dealing with rapidly changing situations so that the Department of Industrial and Trading of Yogyakarta can adjust any changes.

Based on this theory, organizations through Public Relations should be able to find out the character and the public desire, distinguished public-public into certain groups, to determine an appropriate communication strategy formulation for each public. Such matters are conducted solely in order to enhance the positive activity of the respective public. This theory is appropriate for further tracing how function implementation Public Relations conducted by the Department of Industrial and Trading of the city of Yogyakarta. The situation is in this regard that efforts to improve the quality of markets through the Program "Pasare Resik, Atine Becik, Rejekine Apik, Sing Tuku Ora Kecelik ". In this situation, should the party Office can map out how relations should be built on each of the public as well as to determine the appropriate communication strategy, so the message can be read by socializing with both. In General, the public Department of Industrial and Trading of the city of Yogyakarta associated namely Tradingrs, shoppers, workers carrying, janitor, Manager of parking, security officers, and the public.

In this situation, the Department of Industrial and Trading of the city has indeed been realized that it had a diverse public with varying reactions. It has also held activities adapted to the character, desires, and needs of each public. E.g. for Tradingrs, held gatherings, training, and entertainment activities. For the buyer, held the repair facilities and service. As for the labor of 
carrying and janitor, it provides a break room.

However, the researchers noticed that in this situation, the Department of Industrial and Trading of the city of Yogyakarta have not been able to create a positive activity on all their public. For example, not all merchants with the supportive activities undertaken, there is still a lack of awareness of the buyer to participate maintaining facilities provided, and carrying laborers still resting in the halls during the day and go home at night (not utilizing the space break that has been provided). It shows that there are still shortcomings of the Department of Industrial and Trading of the city of Yogyakarta in the public identification and determine strategy. Researchers assess that although it had tried to identify the public and create a wide range of activities, but the implementation is not the maximum. In quantity, the activities performed is indeed quite a lot, but not in quality. With different types of activities, it could not "redirect" all Tradingrs to loyal. With repairrepair facilities, buyers and the general public have not felt would be sure, do not have a sense of belonging, and consciously to safeguard and participate. Researchers assess this is due to the lack of socialization still buyers and the general public of related programs. Then from the labour side carrying the Agency also has not been able to drive to capitalize on the break room that has been provided. Researchers assess due to the break room provided is relatively small and cannot accommodate labor entirely.

In accordance with the name of the program which is "dress rehearsal, Atine $\rightarrow$ Pasare, Rejekine, Sing Tuku Ora Kecelik", should the party Office can realize the market is clean, comfortable, and beneficial to the entire public. However, it is in fact not yet created synergies between public service with all the parties concerned. Yet it cannot identify their public office parties, accommodating his desire, and determine appropriate strategy becomes a cause. An inability to identify these public very likely occurred because the Office of Industrial and Trading of the city has no Public Relations Officer (PRO). Whereas, Public Relations Officer (PRO) needed by the organization because of the highly diverse public. With the ability of the Public Relations Officer (PRO), can help the performance of the Department of Industrial and Trading of the city not only with skills to identify publicly, but also doing the strategy in accordance with the wishes of the public. Given that the Organization could not live without the support of the public, accommodate public desires will create loyalty and liveliness that is positive, so that the objectives of the organization can be more easily realized.

\section{Conclusion}

Forms functions of Public Relations Department of Industrial and Trading of the city of Yogyakarta in the improvement of the quality of the market: Press Agentry, Public Affairs and Community Relations, innovation, Branding Strategy; that can be categorized in the function of Public Relations: build or build positive relationships with the public; create the image of a company or institution; 2-way communication between organizations with their public; and programs that focus on all public organizations. Based on the SWOT analysis, the number of these four variables are not much different. This is in accordance with the deliberations that a variety of activities and efforts already made, but not yet. Solutions offered to maximize activity with the help of a PRO, because the problem lies in the weakness and inability to face the public. Based on the Situational Theory of The Number, the function implementation Public Relations haven't been fullest look from the purpose of the program is not reached for failing to identify the public accommodation, desire, and determining the right strategy. As an organization with a lot of the public, it would be better if the Department of Industrial and Trading of the city of Yogyakarta have PRO or Division who serves as Special 
Public Relations. Then, because the lack of public knowledge about the activities of the program, and need to add the program or can have an impact to the community at large, expanding cooperation with various parties, and increased communication media. The contribution of this research is in the form of policy recommendations to other organizations to implement the public relations function as much as possible to achieve the objectives of the program.

\section{References}

Anggoro, M. Linggar. (2001), Teori dan Profesi Kehumasan serta Aplikasinya di Indonesia. Jakarta: Bumi Aksara. Ardianto, Elvinaro. (2011). Handbook of Public Relations: Pengantar Komprehensif. Bandung: Simbiosa Rekatama Media. Astuty, S., Setyastuti, Y., Maulina, N., \& Hanief, L. (2018). Analisis Fungsi dan Peran Humas dalam Upaya Implementasi Good Governance (Studi pada Bagian Humas Sekretariat Daerah Kota Banjarmasin). Metacommunication: Journal of Communication Studies, 2(1). Cutlip, Scott M., Allen H. Center \& Glen M. Broom. (2009). Effective Public Relations ( $9^{\text {th }}$ edition). USA: Prentice-Hall, Inc.

Fathoni, Abdurrahmat. (2006). Metodologi Penelitian dan Teknik Penyusunan Skripsi. Jakarta: Rineka Cipta Kriyantono, Rachmat. (2014). Teori Public Relations Perspektif Barat Dan Lokal: Aplikasi Penelitian dan Praktik. Jakarta: Kencana. Meisaputra, Abel. (2016). Komunikasi Internal pada Perusahaan yang Tidak Memiliki Humas (Studi pada PT Gotrans Indonesia). Fakultas Ilmu Sosial Ilmu Politik Universitas Sultan Ageng Tirtayasa Serang. Menpan.go.id, Data Statistik Aparatur Negara dalam Smart ASN https://www.menpan. go.id/site/cerita-sukses-rb/menuju-smartasn-2019, diakses pada 22 Maret 2019
Pramudyanto, J. E. (2018). Pentingnya Analisis Swot Dalam Perencanaan Strategi Pemasaran Pada Ud. Yani Bordir Ponorogo (Doctoral Dissertation, Universitas Muhammadiyah Ponorogo). Prayudi. (2016). Strategic Public Relations. Yogyakarta: Komunikasi UPN Press Putra, I Gusti Ngurah. (2008). Manajemen Hubungan Masyarakat. Jakarta: Universitas Terbuka. Rangkuti, Freddy. (2004). Analisis SWOT Teknik Membedah Kasus Bisnis. Jakarta: Gramedia Pustaka Utama. Rencana Strategis Organisasi Perangkat Daerah Dinas Perindustrian Kota Yogyakarta Tahun 2017-2022. Roos Yuliastin. (2017). Manajemen Krisis Public Relations (Studi Kasus tentang Peran Public Relations Badan Pengembangan Wilayah Suramadu (BPWS) dalam Menghadapi Resistensi Masyarakat Madura di Kabupaten Bangkalan terhadap Kehadiran Lembaganya). Jurnal Komunikasi, 11(1), 29-38. Ruliana, P., et.all. (2018). Internal Communication Role in Improving Performance of Employees Hotel: Descriptive Study at Employees Sari Ater Hotel \& Resort in Ciater, Subang Regency, West Java Province. International Journal of Engineering \& Technology, 7(3.30), 259-261. Ruslan, Rosady. (2006). Manajemen Public Relations dan Media Komunikasi: Konsep dan Aplikasi. Jakarta: PT Raja Grafindo Persada. Strauss, A. dan J. Corbin. (2009). DasarDasar Penelitian Kualitatif. Yogyakarta: Pustaka Pelajar. Sugiyono. (2006). Metode Penelitian Kuantitatif Kualitatif dan R\&D. Bandung: Alfabeta. Susi Wulandari. (2018). Peran PR di balik kesuksesan Xpander. MIX 02/XV Maret 2018-April 2018, halaman 27 Wasesa, Silih Agung dan Jim Macnamara. (2010). Strategi Public Relations. Jakarta: Gramedia Pustaka Utama. 